\title{
High-Speed Railways: Present Situation and Future Prospects
}

\author{
Vassilios A. Profillidis, George N. Botzoris \\ Department of Civil Engineering, Section of Transportation, Democritus Thrace University, Xanthi, Greece \\ Email: bprofil@otenet.gr,gbotzori@civil.duth.gr
}

Received January 15, 2013; revised February 15, 2013; accepted February 22, 2013

Copyright (c) 2013 Vassilios A. Profillidis, George N. Botzoris. This is an open access article distributed under the Creative Commons Attribution License, which permits unrestricted use, distribution, and reproduction in any medium, provided the original work is properly cited.

\begin{abstract}
Departing from the present situation, this paper attempts to highlight future prospects of high-speed railways. A panorama of high-speed lines worldwide is first given and the limits of a further increase of rail speeds are surveyed. It is explained that rail high speeds are feasible only for large population concentrations. The impact of high speeds on the reduction of travel times is studied. It is established a causal relationship between rail share and reduced travel times. Diversities concerning technical characteristics from one system to another are emphasized together with differences in construction costs from one case to another.
\end{abstract}

Keywords: Railways; High Speeds; Rail Demand; Population Concentrations; Travel Times

\section{Definition of High Speeds for Railways}

High-speed trains (HST) were the response of railways to the transport market requirement for reduced travel times. However, there is no universally accepted top speed, beyond which a system can be called as high-speed system. It has been generally accepted that the existing conventional railway technology, with improvements in the track and rolling stock, can accommodate top speeds of up to $200 \mathrm{~km} / \mathrm{h}$. Beyond this speed, additional capital costs are needed to meet the requirements of more stringent design features and sophisticated system components. Thus, we consider high-speed trains when V > 200 $\mathrm{km} / \mathrm{h}$. This broad definition of high-speed trains is included in the European legislation, among others in Directive 49/1996 [1].

\section{High-Speed Lines around the World}

High-speed lines were constructed from 1964 to 2013 in the following countries:

- Japan (Tokyo-Osaka-Fukuoka-Kagoshima, TakasakiNagano, Tokyo-Aomori, Tokyo-Niigata).

- France (Paris-Lyons, Paris-Bordeaux, Paris-Marseille, Paris-Lille-Calais, Paris-Strasbourg).

- Germany (Hannover-Würzburg, Mannheim-Stuttgart, Hannover-Berlin, Aachen-Cologne-Frankfurt).

- Italy (Turin-Milan-Bologna-Florence, Rome-Florence,
Rome-Naples).

- Belgium (Brussels-Lille).

- Spain (Madrid-Barcelona, Madrid-Valladolid, MadridCordoba-Seville, Cordoba-Malaga, Madrid-Valencia).

- The Netherlands (Amsterdam-Brussels).

- The United Kingdom (London-Dover).

- Russia (Moscow-St. Petersburg).

- Turkey (Ankara-Istanbul).

- Korea (Seoul-Busan).

- Taiwan (China), (Taipei-Kaohsiung).

- USA (Washington-New York- Boston).

- China (Beijing-Shanghai, Ningbo-Xiamen, ZhengzhouXian, Nanjing-Wuhan-Guangzhou-Shenzhen, BeijingZhengzhou-Wuhan-Guangzhou).

Table 1 illustrates total number of kilometers of highspeed rail lines around the world (in operation (2012), under construction (2012) and planned), with the corresponding maximum speed in each case. A total of 20,819 kilometers of high-speed lines were in operation worldwide in 2012 (2\% of total railway lines all over the world). Though many European countries have planned a number of new high-speed rail lines, the economic crisis in most of these countries may delay or even cancel most of these projects, at least in the forthcoming years. Thus China will be the country, where high-speed rail lines will increase rapidly in the forthcoming years. Indeed, although China is building highways rapidly, it will be 
Table 1. High-speed rail lines (in operation (2012), under construction (2012), planned) in various countries all over the world (compiled from data of [2]).

\begin{tabular}{|c|c|c|c|c|c|}
\hline \multirow{2}{*}{$\begin{array}{l}\text { Continent } \\
\text { and country }\end{array}$} & \multicolumn{5}{|c|}{$\begin{array}{l}\text { Kilometers of high-speed lines } \\
\text { and corresponding speed }\end{array}$} \\
\hline & $\begin{array}{l}\text { Kms in } \\
\text { operation } \\
\text { (2012) }\end{array}$ & $\begin{array}{c}\mathrm{V}_{\max } \\
(\mathrm{km} / \mathrm{h})\end{array}$ & $\begin{array}{l}\text { Kms under } \\
\text { construction } \\
(2012)\end{array}$ & $\begin{array}{c}\mathrm{V}_{\max } \\
(\mathrm{km} / \mathrm{h})\end{array}$ & $\begin{array}{l}\text { Kms } \\
\text { planned }\end{array}$ \\
\hline \multicolumn{6}{|l|}{ Europe } \\
\hline Belgium & 209 & $200-300$ & 0 & & 0 \\
\hline France & 1896 & $300-320$ & 210 & $300-320$ & 2616 \\
\hline Germany & 1285 & $230-300$ & 378 & $230-300$ & 670 \\
\hline Italy & 923 & $250-300$ & 0 & & 395 \\
\hline The Netherlands & 120 & 300 & 0 & & 0 \\
\hline Poland & 0 & & 0 & & 712 \\
\hline Portugal & 0 & & 0 & & 1006 \\
\hline Russia & 650 & 250 & 0 & & 650 \\
\hline Spain & 2056 & $250-300$ & 1767 & $250-300$ & 1702 \\
\hline Sweden & 0 & & 0 & & 750 \\
\hline Switzerland & 35 & 250 & 72 & & 0 \\
\hline United Kingdom & 113 & 300 & 0 & & 204 \\
\hline Total Europe & 7287 & & 2427 & & 8705 \\
\hline \multicolumn{6}{|l|}{ Asia } \\
\hline China & 9302 & $200-300$ & 1336 & $200-300$ & 2,901 \\
\hline Taiwan, China & 345 & 300 & 0 & & 0 \\
\hline India & 0 & & 0 & & 495 \\
\hline Iran & 0 & & 0 & & 475 \\
\hline Japan & 2664 & $250-300$ & 378 & 260 & 583 \\
\hline Saudi Arabia & 0 & & 550 & 300 & 0 \\
\hline South Korea & 412 & 300 & 186 & 300 & 49 \\
\hline Turkey & 447 & 250 & 758 & 250 & 1219 \\
\hline Total Asia & 13,170 & & 3208 & & 5722 \\
\hline \multicolumn{6}{|l|}{ Other countries } \\
\hline Morocco & 0 & & 200 & 300 & 480 \\
\hline Brazil & 0 & & 0 & & 511 \\
\hline USA & 362 & 240 & 0 & & 900 \\
\hline Total other countries & 362 & & 200 & & 1891 \\
\hline Total world & 20,819 & & 5835 & & 16,318 \\
\hline
\end{tabular}

impossible to maintain highway traffic or private car ownership at a level of countries like Portugal. Thus, in order to support mobility in China, high-speed trains may appear as the only cost-efficient and viable solution [3].

In the USA, a number of routes have been suggested as candidates for new high-speed lines, (Table 2). It has been difficult, however, to devise a trustworthy funding model. Most European and Asian high-speed lines have been constructed by public funding. Such a model cannot work in the USA, where a balance and a compromise should be targeted among the private sector, the States and the Federal Government.

\section{Limits of High Speeds for Railways}

Two approaches of high speeds can be distinguished, [1,5]:

- in the first, only passenger trains run on high-speed lines, with low loads per axle, very small tolerances of track defects, and large gradients (up to 35\%o). This approach was implemented in the Paris-Lyons and other lines and presupposes a high passenger train traffic to make the construction and operation of the new line cost-efficient,

- in the second, the new high-speed lines are run by both passenger and freight trains, the coexistence of which entails higher maintenance costs and requires lower values for the longitudinal gradient. Most highspeed lines are currently designed for mixed traffic (both passenger and freight trains).

In any case, for a specific HST system, top speed represents a compromise between the additional capital investment required to achieve a top speed and the higher operating cost and the travel time savings resulting.

High-speed trains operate today with a maximum speed of $320 \mathrm{~km} / \mathrm{h}$, which may be increased up to 350 $\mathrm{km} / \mathrm{h}$ until 2020. However, the Beijing-Shanghai highspeed line was designed for a maximum speed of 380 $\mathrm{km} / \mathrm{h}$, but due to high operating costs maximum speed was reduced to $300 \mathrm{~km} / \mathrm{h}$. Further increase of speed beyond 350 - $380 \mathrm{~km} / \mathrm{h}$, however, looks today difficult to realize due to the following inherent limitations of the rail technology, [6]:

- Difficulty in collecting electric power;

- Reduced adhesion between wheel and rail at higher speeds, causing wheel slip;

- Greater size and weight of on board equipment.

\section{Size of Cities Served by High-Speed Trains}

High speeds require new lines or major improvements on existing lines. The high construction and operation costs cannot be justified unless a large number of rail trips are realized daily. A first index of justification of a new high-speed line may be population concentrations on both ends or along the line (Figure 1). For a new highspeed line to be economically justified, a minimum of ten million people at the one end and four million people at the other may be considered as a rough first criterion. Otherwise, high-speed lines may become a non profitable activity [7]. 
Table 2. Suggested corridors in the USA for new high-speed rail lines [3,4].

\begin{tabular}{|c|c|c|c|c|}
\hline Corridor & $\begin{array}{l}\text { Length of } \\
\text { line }(\mathrm{km})\end{array}$ & $\begin{array}{l}\text { Corridor population } \\
\text { in } 2050 \text { (millions) }\end{array}$ & $\begin{array}{l}\text { Corridor trips in } \\
2050 \text { (millions) }\end{array}$ & $\begin{array}{c}\text { Infrastructure costs } \\
\text { (millions US\$ of year 2009) }\end{array}$ \\
\hline $\begin{array}{c}\text { California (Sacramento-S. Francisco- } \\
\text { Los Angeles-S.Diego) }\end{array}$ & 1751 & 54.1 & 101.0 & $35,904-63,104$ \\
\hline Pacific Northwest (Vancouver-Seattle-Eugene) & 752 & 14.5 & 12.3 & 7005 - 9340 \\
\hline Florida (Tampa-Orlando-Miami) & 769 & 31.6 & 28.9 & $7170-26,768$ \\
\hline $\begin{array}{l}\text { Chicago Hub (Minneapolis-Chicago- } \\
\text { Detroit-Cleveland-Pittsburgh-Kansas) }\end{array}$ & 3497 & 39.1 & 66.0 & $49,151-74,795$ \\
\hline $\begin{array}{l}\text { South Central (Dallas-Austin-S.Antonio, } \\
\text { Dallas-Oklahoma, Dallas-Little Rock) }\end{array}$ & 1934 & 33.0 & 63.9 & $14,424-52,888$ \\
\hline Southeast (Birmingham-Atlanta-Jacksonville-Raleigh) & 2670 & 33.2 & 84.4 & $29,862-49,770$ \\
\hline Gulf Coast (Houston-New Orleans-Mobile) & 1648 & 22.0 & 21.6 & $18,432-30,720$ \\
\hline NEC (Washington-New York-Boston) & 736 & 54.5 & 35.0 & $11,425-26,049$ \\
\hline Keystone (Pittsburgh-New York) & 782 & 16.6 & 9.9 & $11,178-17,010$ \\
\hline Empire (Buffalo-Boston) & 1014 & 28.1 & 22.6 & $12,600-17,010$ \\
\hline Northern New England (Boston-Montreal) & 1070 & 15.3 & 9.9 & $13,300-17,955$ \\
\hline Total & 16,623 & 342.0 & 455.5 & $210,451-385,409$ \\
\hline
\end{tabular}

\section{Impact of High-Speeds on the Reduction of Rail Travel Times}

High-speed rail offers faster travel times than conventional rail, road and air travel between distances of approximately $150 \mathrm{~km}$ and $800 \mathrm{~km}$ [1]. For distances shorter than $150 \mathrm{~km}$, the competitive advantage of highspeed rail over conventional rail is decreased drastically by station processing time and travel to and from stations. For distances longer than $800 \mathrm{~km}$, the higher speed of air travel compensates for slow airport processing times and long trips to and from airports, (Figure 2).

The reduction of travel times was a constant goal of the railways, as can be seen in Figure 3. Only with high speed, however, were the railways able to achieve on 500 - $1000 \mathrm{~km}$ routes travel times equal to or better than air transport and thus compete efficiently with airplanes.

Indeed, high-speed trains capitalize on their advantage to reach city centers and thus make travel times from the center of a city to the center of another far shorter than for automobiles and even, in many cases, shorter than for airplanes.

\section{Impact of High-Speeds on Rail Traffic}

Another result of high speeds was the increase of traffic, either as diverted demand from air and road transport or as totally new demand (generated demand). Figure $\mathbf{4}$ and Figure 5 illustrate high-speed rail traffic in the countries with high-speed lines. Accurate data about China were not available, though high-speed daily ridership was reported to be 349,000 in 2008, 492,000 in 2009 and 796,000 in 2010.

High speeds, therefore, attract back to the railways part of the passenger traffic lost in the past or generate new traffic. For this purpose, however, a speed increase is not enough, station accessibility should also be improved through efficient bus or metro systems. In many instances, connection of railway stations serving HST to the airports can contribute to an efficient (from time and cost point of view) air-rail trip, as explained in next paragraph.

However, the success of high-speed trains is not due only to the reduction of travel times, but also to the following characteristics:

- The frequency of service,

- Regular-interval timetables,

- A high level of comfort,

- A pricing structure adapted to the needs of customers,

- Complementarity with other means of transport,

- More on-board and station services.

A high-speed rail system should be designed to incorporate the whole range of services which the customer has come to expect when traveling on HST, including both pre-travel services (information, ticket purchasing, seat reservation, etc.) and post-travel ones (after-sales services).

\section{Rail and Air Transport: From Competition to Cooperation}

For distances shorter than $500 \mathrm{~km}$ and with travel times less than 3 hours, railways have an advantage over the airplane, since they reach directly the center of served cities. On the other hand, for distances more than 1000 $\mathrm{km}$, the airplane has practically no competitor, as even the high-speed train cannot have travel times for a distance of $1000 \mathrm{~km}$ shorter than $4 \mathrm{~h}[11,12]$. 


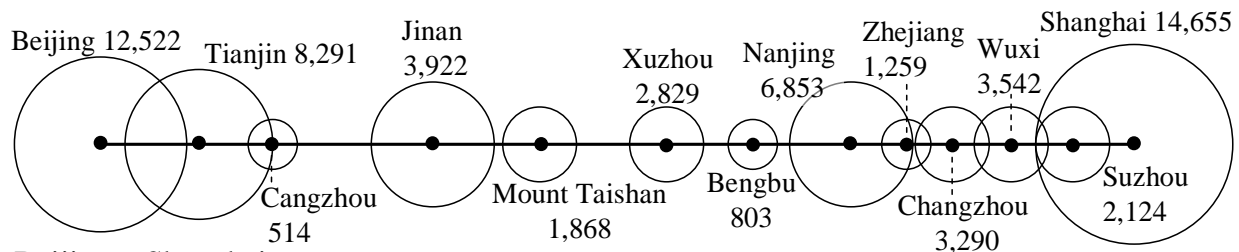

Beijing - Shanghai

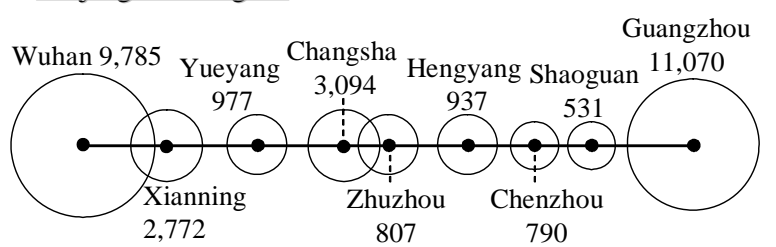

Wuhan - Guangzhou

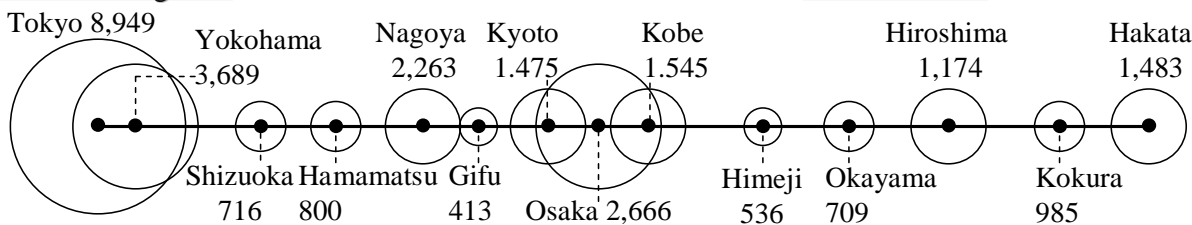

Tokyo - Hakata
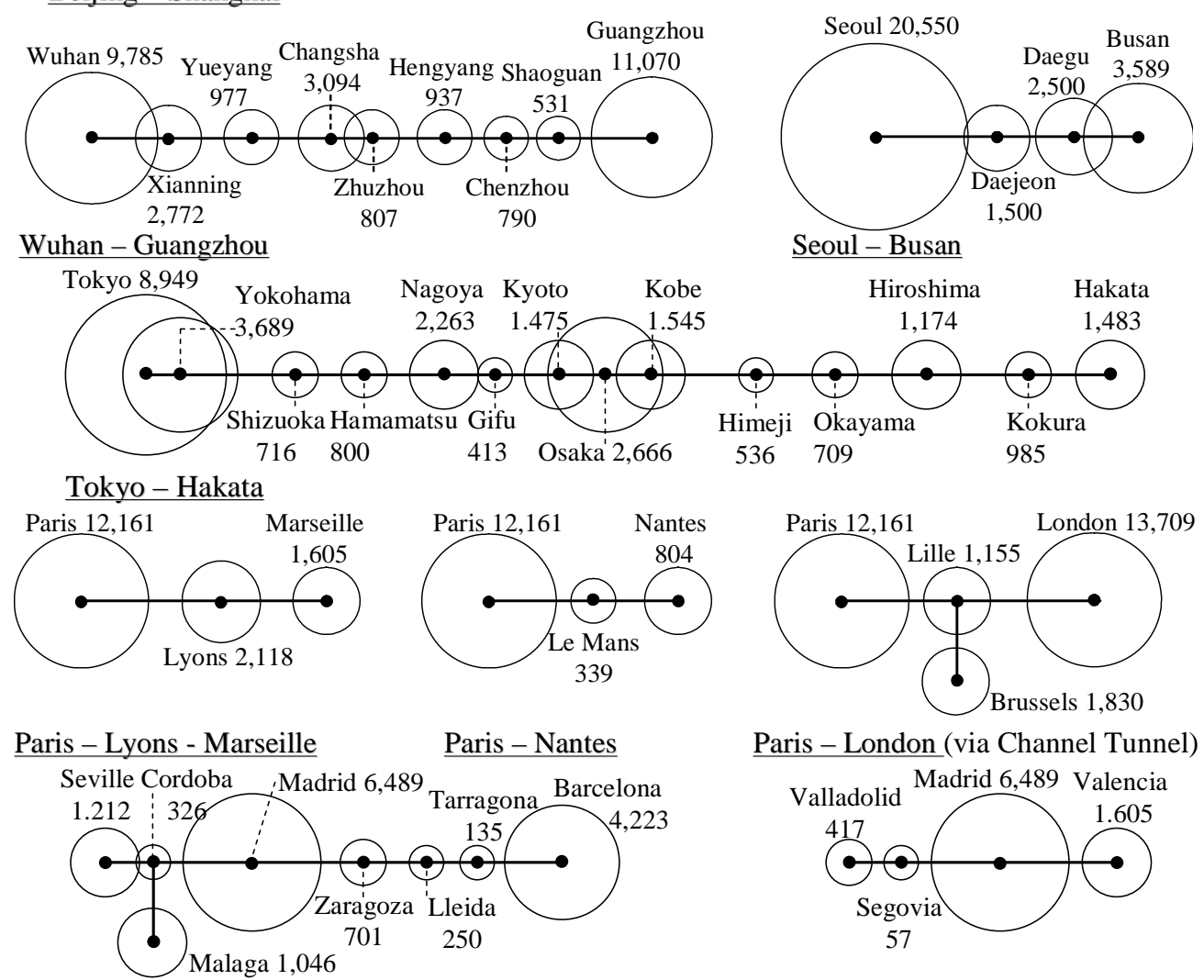

Paris - London (via Channel Tunnel)
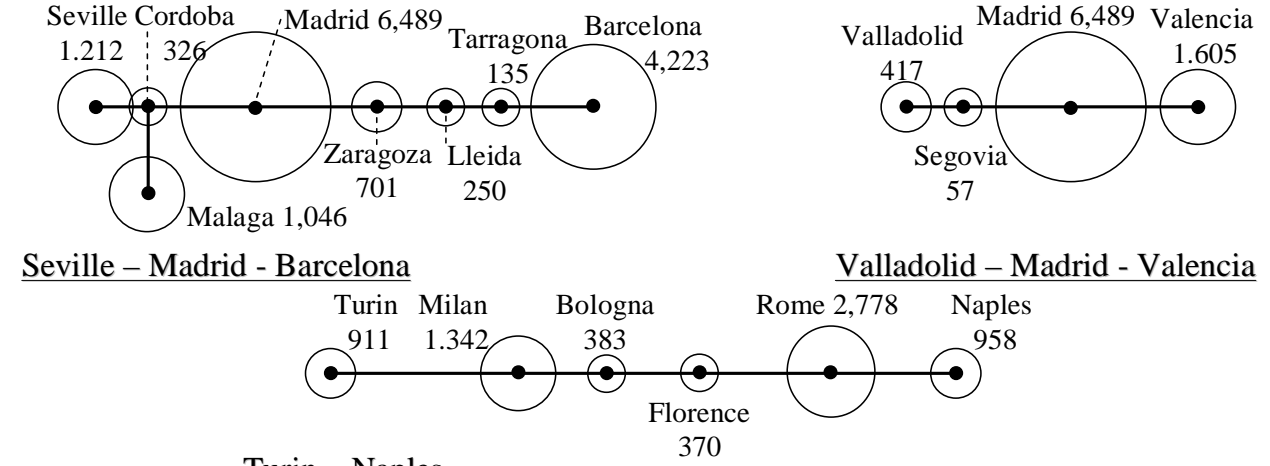

Turin - Naples

Figure 1. Population concentrations (in thousands) along major high-speed lines around the world. The greater area of each city is considered.

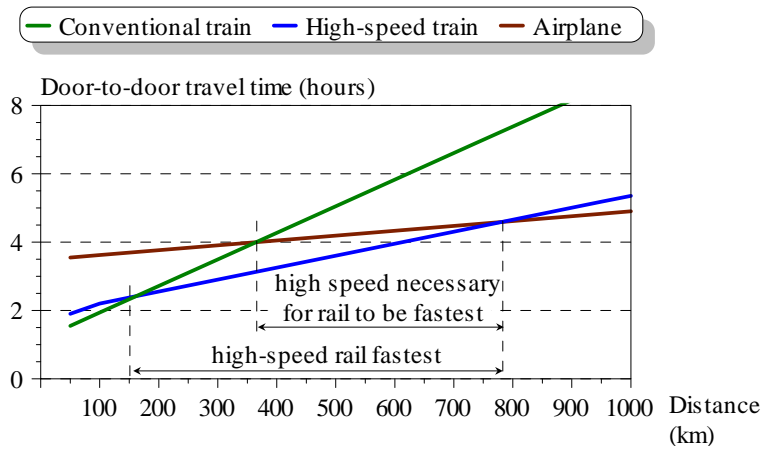

Figure 2. Door-to-door travel time in relation to distance for rail (high-speed and conventional) and air transport [8].
For distances between 500 and $1000 \mathrm{~km}$, rail and air transport are in competition and the rail share depends on travel time (compared to airplane), frequency, quality of service, etc., (Figures 6 and 7).

However, there are two domains where railways and air transport can cooperate complementarily: rail links to airports and medium distance rail connections from airports to other (than the served city) regions [11].

However, rail and air transport can work and cooperate efficiently unless a number of conditions are met [12,13]:

- Physical interconnection of the railway network with the airport, which means that the railway station reaches the airport with direct access to the terminal 


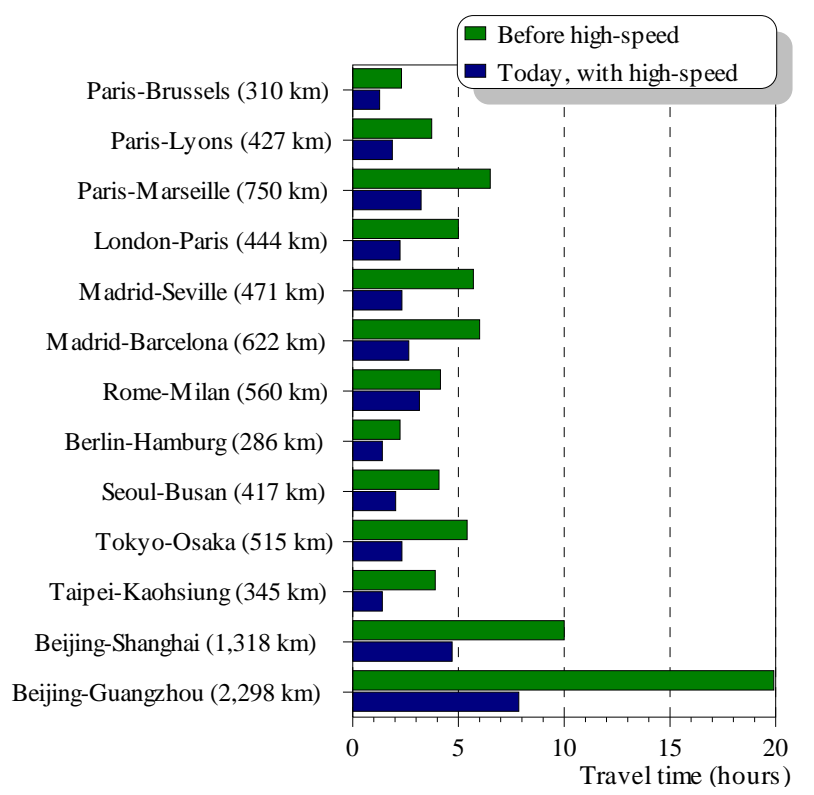

Figure 3. Travel times before and after the introduction of high-speed trains $[1,9]$.
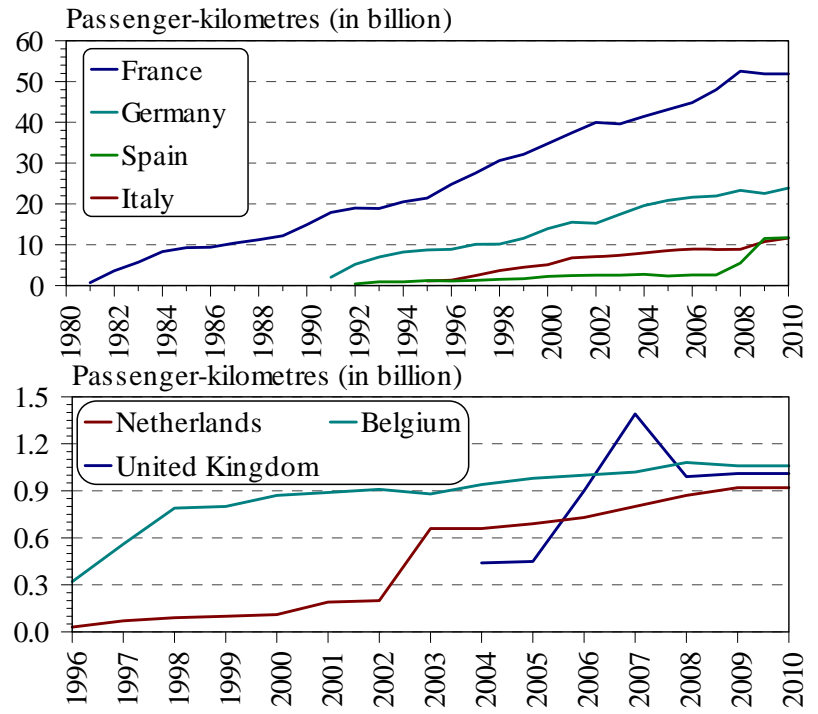

Figure 4. Evolution of high-speed rail traffic in Europe [10].

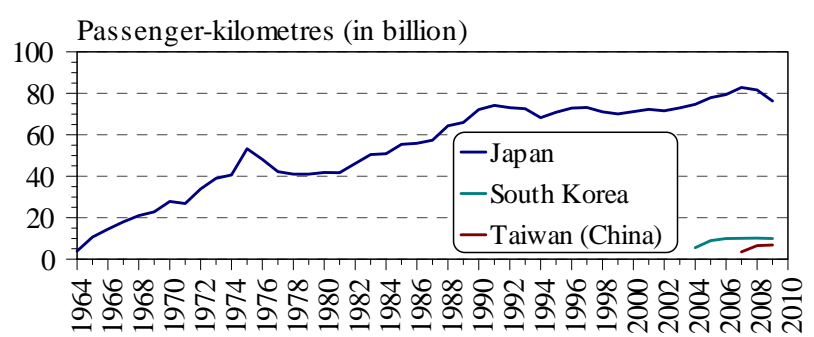

Figure 5. Evolution of high-speed rail traffic in Asia [3,10].

and facilities for the disabled,

- Coordination of the railway timetables with those of the airline companies,

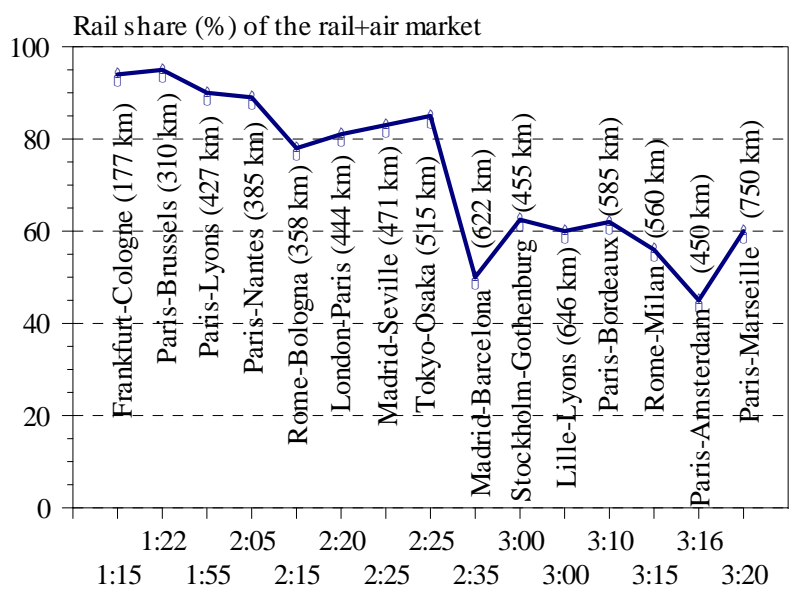

Figure 6. Rail share (for the year 2010) for some high-speed routes, in relation to travel time and distance.

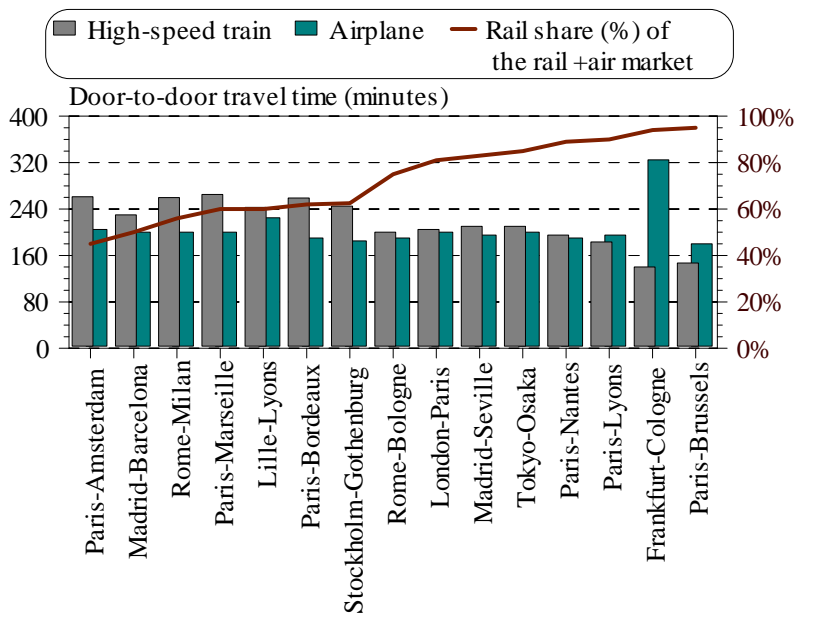

Figure 7. Rail share in relation to door-to-door travel times.

- Combined air/rail tickets with linked fares and simultaneous reservations (i.e. integration of the railway services into the computerized airline system),

- Registration of luggage right to the final destination, which involves overcoming the difficulties associated with safety control.

We tried to survey whether it can be established a causal relationship between rail share and travel time (Figure 8). Indeed, a linear calibration between rail share and travel time gives a rather satisfactory value for the coefficient of determination $\left(\mathrm{R}^{2}=0.76\right)$. This value of $\mathrm{R}^{2}$, though lower than the value of 0.90 , suggested as very satisfactory by some institutions (ICAO, etc.), may well be considered as satisfactory, if we take into account that data are very heterogeneous as they refer to cities and countries spread all over the world. A calibration of rail share in relation to distance has a less satisfactory value for $R^{2}\left(R^{2}=0.67\right)$. However, Figure 8 does not aim to establish any relationship between rail share with cooperation-competition of rail and air transport. 
Table 3. Technical characteristics of high-speed rail lines [1].

\begin{tabular}{|c|c|c|c|c|c|c|c|}
\hline Country & Japan & France & Germany & Italy & Spain & Korea & China \\
\hline Line & $\begin{array}{l}\text { Tokyo-Osaka } \\
\text { (515 km) }\end{array}$ & $\begin{array}{l}\text { Paris-Lyons } \\
\text { (427 km) }\end{array}$ & $\begin{array}{l}\text { Hannover-Würzbu } \\
\text { rg (327 km) }\end{array}$ & $\begin{array}{l}\text { Rome-Florence } \\
\text { (260 km) }\end{array}$ & $\begin{array}{l}\text { Madrid-Barcelona } \\
\text { (622 km) }\end{array}$ & $\begin{array}{l}\text { Seoul-Busan } \\
\text { (417 km) }\end{array}$ & $\begin{array}{l}\text { Beijing-Shanghai } \\
(1,318 \mathrm{~km})\end{array}$ \\
\hline Maximum speed $V_{\max }(\mathrm{km} / \mathrm{h})$ & $260-300$ & 300 & 250 & 250 & 350 & 350 & 380 \\
\hline Radius of Curvature $\mathrm{R}_{\min }(\mathrm{m})$ & 2500 & 4000 & 7000 & 3000 & 4000 & 7000 & 7000 \\
\hline $\begin{array}{l}\text { Maximum longitudinal } \\
\text { gradient (\%) }\end{array}$ & 20 & 35 & 12.5 & 8 & 30 & 25 & 20 \\
\hline Traction power supply & $\begin{array}{l}25 \mathrm{KV} \\
50 \mathrm{~Hz} \text {, } \\
60 \mathrm{~Hz}\end{array}$ & $\begin{array}{l}25 \mathrm{KV} \\
50 \mathrm{~Hz}\end{array}$ & $\begin{array}{c}15 \mathrm{KV} \\
162 / 3 \mathrm{~Hz}\end{array}$ & $3 \mathrm{KV}$ & $\begin{array}{l}25 \mathrm{KV} \\
50 \mathrm{~Hz}\end{array}$ & $\begin{array}{l}25 \mathrm{KV} \\
60 \mathrm{~Hz}\end{array}$ & $\begin{array}{l}25 \mathrm{KV} \\
50 \mathrm{~Hz}\end{array}$ \\
\hline $\begin{array}{l}\text { Distance of axes of } \\
\text { two tracks (m) }\end{array}$ & 4.2 & 4.2 & 4 & 4.2 & n.a. & 5 & n.a. \\
\hline Supereleva-tion (mm) & 200 & 180 & 150 & 160 & n.a. & n.a. & n.a \\
\hline
\end{tabular}

Table 4. Construction costs (values of year 2006) of high-speed tracks constructed during recent years [1,14].

\begin{tabular}{|c|c|c|c|c|c|c|}
\hline Country (Line) & $\mathrm{V}_{\max }(\mathrm{km} / \mathrm{h})$ & $\%$ on ballast & $\%$ on con-crete slab & $\%$ of tunnels & $\%$ of bridges & Construction cost per km (million $€$ ) \\
\hline France (TGV Méditerranée) & 350 & $100 \%$ & - & $6.5 \%$ & $12.7 \%$ & 16.95 \\
\hline \multirow[t]{2}{*}{ Spain (Madrid-Barcelona) } & $270-350$ & $100 \%$ & - & $26.8 \%$ & $3.4 \%$ & 6.12 \\
\hline & & & & $2.0 \%$ & $2.7 \%$ & 3.22 \\
\hline Italy (Rome-Naples) & 300 & $100 \%$ & - & $17.8 \%$ & $24.0 \%$ & 19.58 \\
\hline Korea (Seoul-Busan) & 300 & $82 \%$ & $18 \%$ & $17.8 \%$ & $24.0 \%$ & $42.58^{\mathrm{a}}$ \\
\hline
\end{tabular}

${ }^{\mathrm{a}}$ rolling stock included.

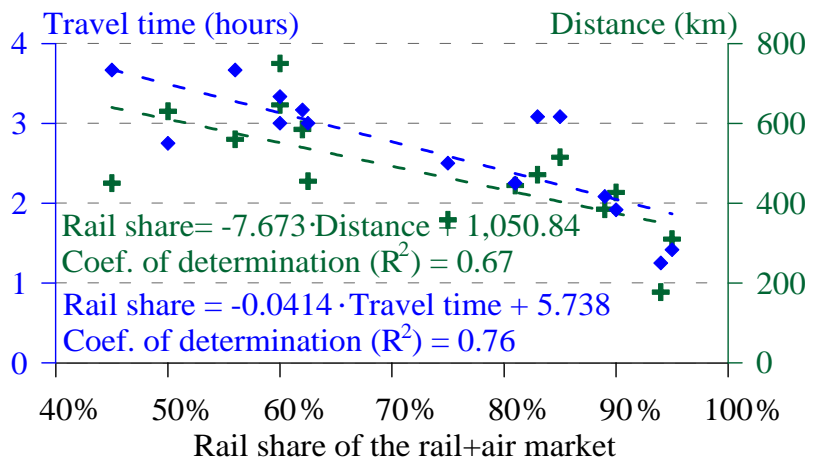

Figure 8. Rail share in relation to distance (green line) and to travel time (blue line).

\section{Technical Features and Construction Costs of High-Speed Railway Lines}

Table 3 illustrates the technical characteristics of some high-speed rail lines. Important differences regarding gradients and electric traction systems are observed $[1,6]$.

Cost data from lines for high speeds constructed during recent years can give a first estimation of the construction cost of a new high-speed railway. In Table 4 high differences in construction costs of high-speed tracks are observed. This is due principally to land costs and labour costs but also to methods of construction and to the bidding procedures for selecting the appropriate constructor [1,6]. Additionally, costs are likely to be lower if countries undertake major high-speed rail construction programs rather than construct a one-off high speed line [14].

\section{Concluding Remarks}

In the present paper we analyzed the various aspects of high-speed railways: reduction of travel times, impact on rail demand, populations served. We surveyed also the technical characteristics and construction costs of highspeed tracks. The analysis illustrates a clear relation between the increase of rail share and reduction of rail travel times. Thus, for distances from 150 to 1000 kilo meters, high-speed trains are a competitive solution for both business and leisure but in some cases even for freight transport.

\section{REFERENCES}

[1] V. Profillidis, "Railway Management and Engineering," Ashgate Publishing Limited, Aldershot, 2006. 
[2] International Union of Railways (UIC), "Railway Statistics,” 2011.

http://www.uic.org/spip.php?rubrique1410

[3] L. Thompson and Y. Tanaka, "High-Speed Rail Passenger Services: World Experience and US Applications," Thompson Galenson and Associates, Saratoga, 2011.

[4] United States Department of Transportation, "Strategic Plan 2010-2015," Washington DC, 2010.

[5] J.-P. Arduin, "Development and Economic Evaluation of High Speed in France,” Japan Railway \& Transport Review, No. 9, 1994, pp. 26-31.

[6] F. T. Najafi and F. E. Nassar, "Comparison of HighSpeed Rail and Maglev Systems," Journal of Transportation Engineering, Vol. 122, No. 4, 1996, pp. 276-281. doi:10.1061/(ASCE)0733-947X(1996)122:4(276)

[7] G. De Rus and G. Nombela, "Is Investment in High-speed Rail Socially Profitable?” Journal of Transport Economy and Policy, Vol. 41, No. 1, 2007, pp. 3-23.

[8] Invensys Rail, “The Benefits of High-speed Rail in Comparative Perspective,” 2012. www.invensysrail.com/whitepapers/hsh-research-report.p df

[9] G. De Rus, "The Economic Effects of High Speed Rail Investment,” OECD/International Transport Forum, 2012. http://www.internationaltransportforum.org/jtrc/discussio npapers/dp200816.pdf
[10] European Union-Directorate General for Energy and Transport, "EU Transport in Figures,” 2012. http://ec.europa.eu/transport/facts-fundings/statistics/doc/ 2012/pocketbook2012.pdf

[11] P. Chiambaretto, H. Dumez and V Profillidis, “Air-Rail Intermodal Agreements as a Way to Access New Markets for Non-Aligned Carriers,” Proceedings of 16th ATRS World Conference, Tainan, 27-30 June 2012.

http://crg.polytechnique.fr/fichiers/crg/perso/fichiers/chia mba_965_Chiambaretto__Dumez_Profillidis_-_Air-rail _intermodal_agreements_as_a_way_to_access_new_mar kets.pdf

[12] D. Banister and M. Givoni, "Airline and Railway Integration,” Transport Policy, Vol. 13, No. 4, 2006, pp. 386397. doi:10.1016/j.tranpol.2006.02.001

[13] A. Couto, "The Effect of High-speed Technology on European Railway Productivity Growth,” Journal of Rail Transport Planning and Management, Vol. 1, No. 2, 2012, pp. 80-88. doi:10.1016/j.jrtpm.2012.05.002

[14] Commission for Integrated Transport, "High-speed Rail: International Comparison,” London, 2004. http://studio.design.upenn.edu/hsr/sites/default/files/CFIT \%202004.pdf 